\title{
Ian Aitken and Michael Ingham, Hong Kong
}

Documentary Film,

Edinburgh, Edinburgh University Press, 2014, 237 pp.

\section{Judith Pernin}

Translator. N. Jayaram

\section{OpenEdition}

\section{Journals}

Electronic version

URL: http://journals.openedition.org/chinaperspectives/6817

DOI: 10.4000/chinaperspectives.6817

ISSN: 1996-4617

\section{Publisher}

Centre d'étude français sur la Chine contemporaine

Printed version

Date of publication: 1 September 2015

Number of pages: $64-65$

ISSN: 2070-3449

\section{Electronic reference}

Judith Pernin, « lan Aitken and Michael Ingham, Hong Kong Documentary Film, », China Perspectives [Online], 2015/3 | 2015, Online since 01 January 2017, connection on 24 September 2020. URL : http:// journals.openedition.org/chinaperspectives/6817 ; DOI : https://doi.org/10.4000/chinaperspectives. 6817 
relationship. Specifically, they put forward a range of policy recommendations and suggest pragmatic steps aimed at reducing areas of friction and expanding areas of cooperation on issues of common concern (from the environment and climate change to proliferation, piracy, and financial stability, etc.). Indeed, none of the American and Chinese contributors believes strategic confrontation between the world's preeminent power and its rising competitor is inevitable. The underlying key thread running throughout the pages of the book is the question of to what extent - and how - strategic distrust can be tamed to facilitate U.S.-China cooperation in bilateral, regional, and global issues, thereby avoiding a military confrontation. It is the balance between these conflicting forces and contradictory logics at play in the U.S.-China relationship - those of strategic distrust versus common interests and cooperation - that might well decide the prospects of great power conflict, or its absence, in the twenty-first century.

I Hugo Meijer is lecturer in defence studies, King's College London, and research associate, Sciences Po-CERI, Paris (hugo.meijer@kcl.ac.uk).

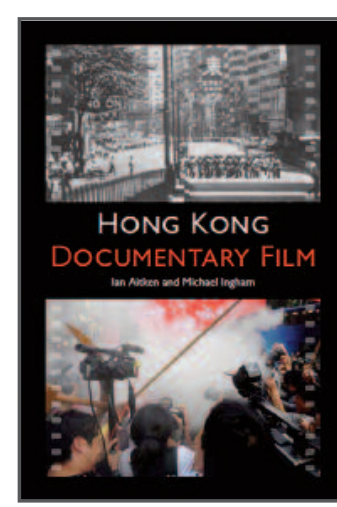

\section{Ian Aitken and Michael} Ingham, Hong Kong Documentary Film, Edinburgh, Edinburgh University Press, 2014, 237 pp.

\section{JUDITH PERNIN}

U ntil recently, even the best informed cinephiles and scholars would have been hard pressed to name any Hong Kong documentaries or academic work on the subject. The colonial nature of public audiovisual institutions before the handover in 1997 and Hong Kong cinema's commercial orientation certainly accounted for the low visibility of local productions, dominated as they were by imperatives other than the purely cinematographic. Moreover, Chinese language cinema's transnational dimension and Hong Kong's particular status vis-à-vis the People's Republic of China also made for poor appreciation of its contribution to the history of this form. The works of PRC scholars do consider the contributions of Hong Kong studios dealing with mainland China, but hardly anything is said about truly local productions and even less about those put out by colonial institutions. (1) In any case, most of these documentaries are difficult to come by, having been lost or damaged following the transformations of Hong Kong's audio-visual industry.

Given that documentary cinema is to a large extent linked to politics, its history cannot be written without considering public cinematographic and televisual institutions, nor without referring to the more general context of their place of production. This is precisely what lan Aitken and Michael Ingham set out to do in this book by focusing on the history of Hong Kong's audio-visual structures, and by featuring film analyses that illustrate the form's diversity.
For instance, in the first chapter, Aitken retraces the origins of $A$ Page of History, Lai Man-wai's film made from newsreel footage shot throughout the 1920s and edited together in 1941. The film, in homage to Sun Yat-sen, often appears in mainland publications for its account of the Northern Expedition. It is re-examined here in light of new research on its conditions of production and distribution, relying on two versions of the film preserved in Beijing and Hong Kong and restored early in the last decade. Chapter 2 deals with among others "Picturesque committed films" by local private companies that championed Leftist ideas in the period 1947-69. Analysis of the documentary Water Comes Over the Hills from the East (Lo Kwanhung, 1965) shows how the director adapted a historical water shortage crisis to glorify the Chinese government.

Such a clearly partisan dimension comes through entirely differently in official productions, i.e. colonial ones, considered in the next two sections. Chapter 3 examines the Hong Kong Film Unit (HKFU, 1959-1973) based on studies by Aitken of colonial film and of John Grierson. ${ }^{(2)}$ As the progressive leader of the British documentary movement in the 1930-40s, Grierson was also instrumental in setting up or influencing the Commonwealth public documentary institutions, including those in British colonies. But Aitken shows that unlike in Australia, New Zealand, or even India, HKFU productions had the sole objective of promoting Colonial Office "propaganda and education" (p. 76). HKFU's news and educational documentaries were duly screened between advertisements and full-length films in cinema halls or shown by mobile teams in refugee camps. Aitken draws attention to these films' wilful myopia in avoiding any direct reference to China, even during such tragedies as the Great Leap famine (1959-1961), although that very event had led to the massive influx of refugees to Hong Kong. Local social and political problems such as the 1967 riots were also ignored in Hong Kong Today news, more proof that, "This can hardly be said to constitute an attempt to use the official film in an interventionist, reform-oriented, 'Griersonian' way" (p. 83). Moreover, as the colonial government had not thought it necessary to endow the territory with substantial cinematographic structures, more prestigious "public relations" documentaries vaunting the Hong Kong success story for the local and overseas markets were actually made in collaboration with foreign companies such as Singapore's Cathay. This was the case with This is Hong Kong (Noni Wright, 1961), a film whose fame is assured thanks to its appropriation in One Way Street on a Turntable (Anson Mak, 2007) more than due to its own quality.

Chapters 4 and 5 offer an account of the evolution of television documentaries while Hong Kong was transiting from being a colony to a Special Administrative Region of China. Aitken focuses on the way in which politics translate into RTHK's public service productions and the programmes of ATV and TVB chains, whose commercial interests were becoming increasingly indistinguishable from those of China. The complexity of Hong Kong television stations' stances especially around 1989 is brought out through several documentaries such as the outstanding Spring of Discontent (TVB), a surprising film in the Direct Cinema style on the democratic movement

1. Fang Fang, Zhongguo jilupian fazhan shi (A history of the development of Chinese documentaries), Beijing, Zhongguo xiju chubanshe, 2003, 553 pp.; and Shan Wanli, Zhongguo jilu dianying shi (History of Chinese documentary films), Beijing, Zhongguo dianying chubanshe, 2005, 455 pp.

2. Studies carried out with a network of researchers on colonial documentary films: see http://documentary-film.af.hkbu.edu.hk (accessed on 3 July 2015) and two articles by lan Aitken: "The Development of Official Film-Making in Hong Kong," Historical Journal of Film, Radio and Television, Vol. 32, No. 4, 2012, pp. 589-609; and "Television documentary film in Hong Kong: The case of Hong Kong's two terrestrial television broadcasters," Studies in Documentary Film, Vol. 9, No. 2, 2015, pp. 95-113. 
in Tiananmen Square broadcast just two days before the bloody repression of 4 June 1989. The more conventional Hong Kong Case (RTHK, 1989) goes over the colony's history and the handover process. Ordinary Hongkongers and noted politicians voiced their opinions on the future even as the colony was recovering from the Tiananmen trauma. Among those interviewed were pro-democrat leader Martin Lee and current Chief Executive Leung Chunying, then secretary general of the Basic Law Drafting Committee.

The book ends with two chapters by Ingham on independent documentaries (1973-2013), on which he has already written, especially in one of the rare collective publications on Hong Kong screen arts. (3) His panorama of diverse initiatives and structures that led to the rise of independent documentaries in Hong Kong forms a necessary companion to the rest of the book, as it shows that more personal voices exist in addition to those of commercial and official productions. In contrast to the preceding chapters, Ingham chooses an auteur approach befitting the personality of directors as diverse as Shu Kei, Evans Chan, Anson Mak, Louisa Wei, Cheung King-wai, and Tammy Cheung. Each film analysis is rooted in its own references, either to theatre, film essay, direct cinema, or experimental film, stressing that while these works all discuss local politics, they also introduce a more social and artistic dimension to Hong Kong documentaries.

A filmography of works discussed as well as a list of public institutions or private companies mentioned would have been a useful addition to a book that one hopes will encourage more scholars to write on the subject. Despite the limitations of a publication covering such vast ground, Hong Kong Documentary Film not only fills a gaping void in studies on this film form, but also responds to the pressing need to examine the history of Hong Kong documentaries from a local viewpoint without excluding television productions or the colonial dimension of some of these films.

I Translated by N. Jayaram.

I Judith Pernin is associate researcher at CEFC

(judithpernin@gmail.com).

3. Esther M. K. Cheung, Gina Marchetti, See-Kam Tan (eds), Hong Kong Screenscapes: From the New Wave to the Digital Frontier, Hong Kong, Hong Kong University Press, 2011, 316 pp. Michael Ingham is also the author of "Twenty years on: Hong Kong dissident documentarians and the Tiananmen factor," Studies in Documentary Film, Vol. 6, No. 1, 2012, pp. 81-97, and of "A Personal Vision of the Hong Kong Cityscape in Anson Mak's Essayistic Documentary Films One Way Street on a Turntable and On the Edge of a Floating City, We Sing," in Camille Deprez and Judith Pernin (eds), Post-1990 Documentary: Reconfiguring Independence, Edinburgh, Edinburgh University Press, 2015, pp. 151-171.

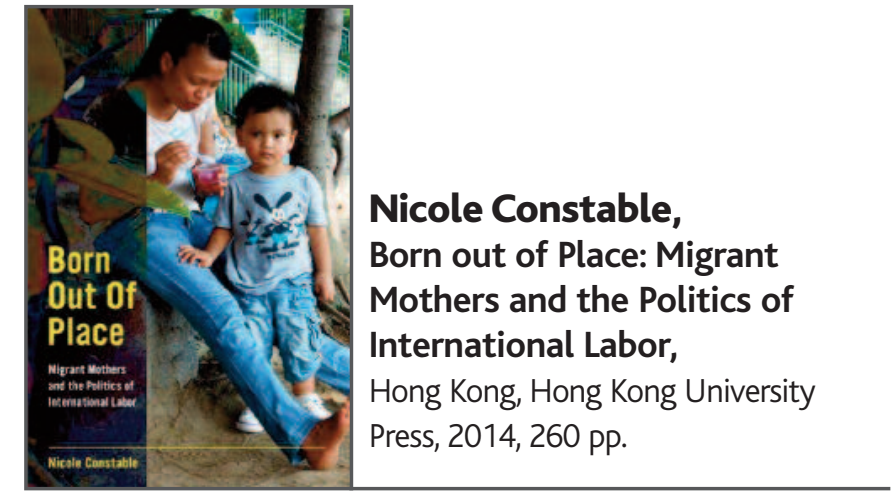

\section{SIUMI MARIA TAM}

T his book is a recent addition to Constable's series of research on migrant women as foreign domestic workers (FDWs) in Hong Kong. Like the other publications before it, this book contains rich ethnographic data as well as serves as a sympathetic call for attention to the plight of migrant women workers from Southeast Asia. But quite unlike the rest, this book focuses on the particular difficulties of FDWs as mothers who become pregnant and give birth to babies in Hong Kong. By weaving ethnographic observations and theoretical arguments, the book offers details of the challenges that mothers and children face, some of the choices they have, the different paths they take, and the roles of the fathers and social institutions in shaping them. These together put forward a convincing case of transnational migrant labour as not an individual woman's choice, but rather a coproduction of personal, familial, institutional, and global factors.

The book is divided into eight chapters. In the first chapter, "A Very Tiny Problem," Constable outlines a broad framework of the significant actors in the making of the FDWs' world, in particular how government policy has constructed a frame, literally, that cages migrant women workers physically, socially, and culturally, as well as emotionally. The resultant problems are sometimes temporary, but when a child is involved, the problem is complicated and lasts a lifetime. Although in mainstream society, migrant women workers and their problems could be considered a matter of human rights and thus attract the attention of NCOs and some sympathy from the more liberal-minded, FDWs' pregnancies and babies are often shunned, trivialised, and largely ignored. This could partly be due to the small number of babies involved, but more importantly it is related to a mentality that sex is an individual and moral issue. If FDW single mothers are labelled as "adulterers, prostitutes, and "bad girls"' (p. 10) they will not be pitied. Coupled with this, migrants in general are considered poor and unwelcome, as well as powerless and easily victimised. These stereotypical images of FDWs are not limited to their employers, but exist among almost everyone involved in the network of transnational migration. These include, for example, employment agency staff, immigration and court officials, and ironically even social workers at NGOs and the FDWs themselves. The co-agency and intersubjectivity of this network obviously has a class basis, and the chapter succinctly puts forward a complex case of how class is interwoven with ethnicity, gender, and family duties, as well as women's sexuality.

Chapter 2 reviews the academic literature on migrant domestic workers, dividing them into two broad categories: the first one emphasises the negative side of things - exploitation, abuse, and oppression in global capitalism - while the other sees migration as a resource, noting how migration brings about new agency, pleasure and desire, etc. (p. 23). Constable argues that it 